\title{
Una familia de prestamistas y arrendadores judíos en tiempos de la expulsión: Los Soto de Aranda de Duero
}

\author{
ENRIQUE CANTERA MONTENEGRO*
}

\begin{abstract}
RESUMEN
ABSTRACT

En este trabajo se estudian los últimos años de la presencia en suelo hispano de la familia de los Soto, judíos vecinos de la localidad burgalesa de Aranda de Duedo. Dedicados de forma prioritaria al arrendamiento de rentas $y$ al préstamo con interés, eran propietarios de importantes bienes raíces tanto en la villa de Aranda y su tierra como en otras localidades próximas. El análisis de la documentación disponible permite apreciar las dificultades a que tenian que hacer frente los arrendadores judíos en los años inmediatamente precedentes al edicto de expulsión y, especialmente, como consecuencia de su promulgación el 31 de marzo This report deals with the last years of the Soto family in Spain, jewish people living in Aranda de Duero, a town in the province of Burgos, where they owned real estate properties, there and in the sorrownding area. Their main duty was to lease land and to obtain rents from loans. The documentation available shows the difficulties the jewish owners had to face during the preceeding years of the Royal Decree of expuision and specially, the consequences of its promulgation in March, 31st. 1492.
\end{abstract}

* UNED. 
Son ya suficientemente conocidas las líneas generales de la evolución histórica de la minoría judía en los últimos años de su presencia en los reinos hispanos '. No obstante, el análisis de la abundante documentación que aún se conserva inédita relativa a distintas aljamas hispano-hebreas, sigue siendo de fundamental importancia en orden al mejor conocimiento de las múltiples facetas que en los años finales del siglo xv presenta la comunidad judia. Y a ello puede contribuir decisivamente el estudio de personajes o de grupos familiares concretos, al aportar datos singulares que permitan corroborar o, por el contrario, modificar las hipótesis generales ya formuladas ${ }^{2}$.

Hace ya varios años me interesé por el estudio de los pleitos que, con motivo de numerosos contratos de préstamo con interés suscritos entre judíos y cristianos, se suscitaron a fines del siglo $\mathrm{xV}$ en diversas poblaciones de la diócesis de Osma ${ }^{3}$, territorio éste en el que, como señala el profesor Suárez Fernández, las querellas de usura alcanzaron una gran amplitud y virulencia en los años inmediatamente anteriores a la promulgación del edicto de expulsión ${ }^{4}$. En dicho estudio pudo demostrarse la importancia de las relaciones contractuales entre judíos vecinos de diversas aljamas burgalesas y sorianas situadas a lo largo del curso del río Duero y cristianos habitantes de pequeños núcleos campesinos de su entorno; la naturaleza de los productos - moneda, pan, ganado-y las pequeñas cantidades contratadas permiten suponer que los prestatarios eran, generalmente, pequeños campesinos que se veían obligados a solicitar un préstamo ante una mala cosecha ${ }^{5}$. Pero si lo más frecuente es que los judíos aparezcan en la documentación como prestamistas y acreedores, hay también algunos casos en los que figuran como prestatarios y deudores. A este respecto no debe olvidarse que, del mismo modo que la Iglesia prohibia el préstamo con interés entre cristianos, una prescripción talmúdica lo prohibía entre judíos, por lo que en caso de necesidad solían acudir a prestamistas cristianos. Asimismo concluía en dicho estudio la

\footnotetext{
1 Merecen ser destacadas, entre otras, las obras de Luis SUÁREZ FERNÁNDEZ, Documentos acerca de la expulsión de los judios, Valladolid, C.S.I.C., 1964, y La expulsión de los judios de España, Madrid, Mapfre, 1991, o la de Joseph PÉREZ, Historia de una tragedia. La expulsión de los judios de España, Barcelona, Crítica, 1992.

Pueden resultar modélicos a este respecto los trabajos de Béatrice LEROY, «Une famille de la Juiverie de Tudela aux Xille et XIVe siècles: les Ménir», en Revue des Études Juives, 136 (1977), págs. 277-295, y Les Menir, une famille sépharade à travers les siècles (Xlle-XXe siècles). París, 1985.

Enrique Cantera Montenegro, "Pleitos de usura en la diócesis de Osma en el último tercio del siglo XV», en Anuario de Estudios Medievales, 12 (1982), págs. 597-622.

${ }^{4}$ Luis SuÁrez Fernández, Documentos acerca de la expulsión de los judíos, pág. 28.

5 Enrique CANTIERA, Op. cit., pág. 611.
} 
absoluta necesidad de los contratos de préstamo entre judíos y cristianos, sujetos a las disposiciones emanadas de las Cortes de Madrigal de 1476, que continuamente son señaladas como punto de referencia en los frecuentes pleitos que surgían como consecuencia de las operaciones de préstamo ${ }^{6}$.

Ahora me intereso por una familia concreta, los Soto, vecinos de la localidad burgalesa de Aranda de Duero, de algunos de cuyos miembros se conservan bastantes noticias documentales relativas a los diez años inmediatamente precedentes a la salida de los judíos de los reinos hispanos. El estudio de la documentación conservada permite comprobar que se trata de una familia de gran relevancia, no sólo en la vida de la comunidad hebrea arandina sino también en la de esta localidad en general. No en vano, de los ocho de sus miembros de los que poseemos alguna noticia, cuatro reciben el título de don, cuyo uso estaba teóricamente vedado a los judíos; son los hermanos don Yuça, don Simuel y don Yuda de Soto, y la mujer del primero doña Bienvenida. Asimismo, los otros cuatro integrantes de esta familia documentados son nombrados como rabíes; son rabí Simuel, rabí Aby, rabí Mose y rabí Ça, todos ellos hijos de Simuel de Soto. También en una ocasión es citado como rabi don Yuda de Soto.

Otro dato que corrobora la importancia de esta familia lo encontramos en las relaciones («repartimientos») del tributo conocido como servicio de los castellanos de oro correspondientes a los años 1488 y 1490; en ellas aparece citado don Simuel de Soto, vecino de Aranda de Duero, contribuyendo junto con la aljama de Roa. Las cantidades con las que debía contribuir don Simuel eran de 2.590 maravedíes en 1488 (de un total de 5.207 maravedíes que debían satisfacer los judíos de Roa), y de 4.054 maravedíes en 1490 (de un total de 5.748 maravedies) ${ }^{7}$, lo que por sí solo es suficiente para hacerse idea de la capacidad económica de este personaje. Como se indicará en otro lugar, cabe sospechar que don Simuel de Soto fuera en 1492 la máxima autoridad de la aljama arandina.

Por otra parte, la dedicación profesional prioritaria de los diversos integrantes de esta familia era el arrendamiento de rentas (tanto reales como eclesiásticas y, posiblemente también, concejiles) y el préstamo con interés, que eran las actividades propias del sector más poderoso económicamente de las comunidades hispano-hebreas en época bajomedieval. Asimismo eran propietarios de importantes bienes raíces - casas, viñas - situados no

Enrique Cantera, Op. cit, pág. 611.

L. SuÁREZ, Documentos acerca de la expulsión de los judios, pág. 70. 
sólo en la villa de Aranda de Duero y en su tierra, sino también en otras localidades no muy distantes como Roa o Gumiel de Mercado.

Un análisis detenido de la documentación disponible - toda ella procedente del Registro General del Sello, del Archivo General de Simancas, y de la que en apéndice documental se ofrece una selección de los documentos de mayor interés-, permite apreciar las enormes dificultades que debían superar los arrendadores y los prestamistas judíos en el desempeño de sus actividades; si en unos casos parecen ser víctimas de los odios y de las envidias de sus deudores y de las personas con las que arrendaban conjuntamente alguna o algunas rentas, en otros parece traicionarles un ánimo excesivo de lucro, lo que era condenado por las propias autoridades civiles y religiosas judías como abiertamente contrario a los intereses de la comunidad hebrea ${ }^{8}$. Esta documentación ofrece también noticias de interés acerca de las complejas situaciones que se plantearon en relación con los contratos de arrendamiento de rentas y de préstamo con interés con ocasión de la promulgación del edicto de expulsión general de los judíos de 31 de marzo de 1492. Pues, una vez más a través de la documentación disponible, parece desprenderse que la mayor parte de los miembros de la familia Soto optó por el exilio en 1492.

El personaje que con mayor frecuencia aparece citado en la documentación es don Yuçe (o Yuça, que de las dos formas aparece nombrado) de Soto, vecino de Aranda de Duero, y casado con doña Bienvenida, judía vecina de la misma localidad burgalesa. Se trata de un hombre rico, que era propietario de diversos bienes raíces en Aranda de Duero y en Roa, y que se dedicaba de forma prioritaria al préstamo con interés y al arrendamiento de rentas. Los últimos años de la presencia judia en los reinos hispanos fueron para él particularmente azarosos, con ocasión de las diferencias que tuvo con algunos socios suyos en el arrendamiento de rentas, lo que, incluso, le llevó a la cárcel. El asunto es sumamente complejo, y en él se suceden las denuncias de diversos acreedores de don Yuçe de Soto y los recursos de éste y de su mujer ante las justicias regias; asimismo son interesantes las peripecias relativas a la huida de don Yuçe de la cárcel de Aranda en la que estaba recluido, y la apropiación por parte de

8 Así, por ejemplo, en el capíulo quinto de las Taqqanoth de Valladolid de 1432, en el que se recogen diversas disposiciones acerca de las costumbres en el vestir, prohibiéndose el uso de tejidos ricos, por cuanto provocaban la envidia de los conciudadanos cristianos y, además, por no ser acordes con la situación de destierro en la que se encontraba el pueblo judío. Una excelente edición de estas Taqqanoth puede encontrarse en Yolanda MORENO KoCH. Fontes ludaeorum Regni Castellae. V. De iure hispano-hebraico. Las Taqqanoth de Valladolid de 1432. Un estatuto comunal renovador. Universidad Pontificia de Salamanca-Universidad de Granada, 1987. 
doña Bienvenida de todos los bienes de su marido que pudieran ser objeto de embargo por las autoridades judiciales con el fin de atender las demandas de sus acreedores.

En el año 1480 don Yuçe de Soto arrendó en ciento diez mil maravedíes las tercias de la villa de Aranda de Duero y su tierra correspondientes a los años 1481 y 1482 . Algún tiempo después, conjuntamente con su mujer doña Bienvenida, arrendó la renta de los pontificales ${ }^{9}$ de Aranda de Duero de 1482 y 1483 en cien mil maravedíes, y en compañía de Catalina González, viuda de Diego de Requena y vecina de Aranda, la misma renta de los pontificales de esta población correspondiente al año 1484.

Y fue precisamente con motivo del arrendamiento de estas últimas rentas como surgió el pleito que llevó a don Yuçe de Soto a la cárcel. Desconozco el motivo concreto de las diferencias surgidas entre Catalina González y don Yuçe de Soto, pero de lo que no existe ninguna duda es de que aquélla consiguió una carta de «recurso» del provisor del obispado de Osma, en virtud de la que se procedió al encarcelamiento de don Yuçe de Soto en la prisión de Aranda de Duero ${ }^{10}$. En algún otro documento se indica que la prisión obedeció a las deudas que don Yuçe tenía con algunos vecinos de Aranda de Duero y de otras diversas localidades ${ }^{11}$.

Tras algún tiempo de estancia en prisión, don Yuçe de Soto huyó de ella una noche, desconozco si en connivencia con los oficiales encargados de su vigilancia o como consecuencia de la tradicional inseguridad de las cárceles públicas de las ciudades de época medieval. Inmediatamente, sus acreedores reclamaron a Aparicio de Gormaz, alguacil de Aranda de Duero, que se hiciera cargo de las deudas que don Yuçe de Soto tenía con ellos, pues a él hacían culpable de su huida. Pero el Consejo Real ordenó un aplazamiento de cualquier medida contra el alguacil, y se dirigió a los corregidores y demás autoridades concejiles de las villas de Roa, Cuéllar y Peñafiel ordenándoles que si don Yuçe de Soto se encontraba en cualquiera de ellas que procedieran a detenerlo inmediatamente y a entregarlo a Aparicio de Gormaz ${ }^{12}$. Parece razonable suponer que existían indicios acerca de dónde podía encontrarse refugiado don Yuçe de Soto, quizá porque en estas localidades dispusiera de bienes inmuebles o en ellas ejerciera sus actividades de prestamista y arrendador de rentas.

9 Renta de los diezmos eclesiásticos correspondientes a una parroquia.

10 Archivo General de Simancas (en adelante A.G.S.), Registro General del Sello (en adelante R.G.S.), fol. 108; documento de 18 de abril de 1485. Apéndice documental, núm. 3.

1 A.G.S., R.G.S., fol. 182; documento de 14 de febrero de 1485 .

12 A.G.S., R.G.S., fol. 182; documento de 14 de febrero de 1485. 
Entre los diversos acreedores de don Yuçe de Soto figura Diego de Valladolid, aposentador real, quien reclamó ante el Consejo Real que se ejecutara en los bienes de este judío una sentencia que había obtenido de las justicias de Aranda, en la que se ordenaba que se le hiciera entrega de dos pares de casas propiedad de don Yuçe de Soto, en compensación por los cuarenta mil maravedíes que éste le debía - sin duda como consecuencia del impago de un contrato de arrendamiento de rentas-, y que no podía cobrarlos por hallarse ausente de dicha villa. Don Yuçe debía ser un personaje bien relacionado —es posible que aquí radique la explicación de su huida de la cárcel-, pues la queja de Diego de Valladolid obedecía, fundamentalmente, a que no conseguía que los alcaldes y justicias de la villa de Aranda de Duero ejecutaran la sentencia que ellos mismos habían dictado sobre los bienes de don Yuçe de Soto, dilatando su aplicación práctica ${ }^{13}$.

Otro de los acreedores era Juan de Figueroa, recaudador real, quien reclamaba que se hiciera ejecución en ciertos bienes muebles que don Yuçe de Soto tenía en Roa, en compensación por los ciento diez mil maravedíes que éste le debía de las rentas de las tercias de la villa de Aranda de Duero y su tierra correspondientes a los años 1481 y 1482, que había tenido arrendadas, y que no le había abonado al huir de la villa de Aranda ${ }^{14}$.

El alguacil de Aranda de Duero, Aparicio de Gormaz, logró localizar a don Yuçe de Soto en la localidad segoviana de Cuéllar, pero no lograba que le fuera entregado por el alcálde de esta villa, el licenciado Diego de Álava, quien se resistía a ejecutar la orden de detención dictada por el Consejo Real. Esta dilación habría posibilitado que don Yuçe se refugiara en el castillo de esta localidad, lo que es una nueva e inequívoca señal de las excelentes relaciones que este personaje debía mantener con distintas autoridades locales, y en este caso también con el alcaide de la fortaleza de Cuéllar. El alguacil arandino logró en esta ocasión dos cartas del Consejo Real, una de fecha 9 de marzo de 1485 en la que se ordenaba a las justicias de Roa, Peñafiel y Cuéllar, así como al ejecutor real Pedro de Aranda, que prendieran a don Yuçe de Soto y que lo entregaran a Aparicio de Gormaz ${ }^{15}$, y otra de 10 de marzo en la que se concedía al alguacil de Aranda de Duero una prórroga de cuarenta días para que procediera a la detención de don Yuçe de Soto, sin que entre tanto los acreedores del judío pudieran proceder ni contra él ni contra sus bienes ${ }^{16}$.

A.G.S., R.G.S., fol. 77; documento de 7 de febrero de 1484.

A.G.S., R.G.S., fol. 105; documento de 14 de marzo de 1485. Apéndice documental, núm. 2.

A.G.S., R.G.S., fol. 102; documento de 9 de marzo de 1485. Apéndice documental, núm. 1.

16 A.G.S., R.G.S., fol. 148; documento de 10 de marzo de 1485. 
La carta conminatoria del Consejo Real forzó finalmente la entrega de don Yuçe de Soto por parte del alcaide de la fortaleza de Cuéllar a Aparicio de Gormaz, quien seguidamente lo trasladó de nuevo a la cárcel pública de Aranda de Duero. Pero el caso iba a complicarse aún más, ya que, a petición de Catalina González, los alcaldes de Aranda ordenaron también que fuera presa doña Bienvenida, mujer de don Yuçe de Soto; asimismo, el provisor de la diócesis de Osma ordenó el embargo y secuestro de ciertos bienes de doña Bienvenida, pese a que ésta insistía en que eran bienes recibidos de su marido en dote. La reclamación de ésta desde la cárcel no se hizo esperar, alegando ante la justicia regia que ella no tenía ninguna relación con el asunto por el que había sido encarcelado su marido y quejándose, además, por la intromisión del provisor del obispado, ya que en su opinión no tenía autoridad para entrometerse en este asunto por cuanto Catalina González y ella eran personas seglares y sometidas, por tanto, a la jurisdicción real. La intromisión de la justicia eclesiástica obedecía, con toda probabilidad, a que las diferencias entre Catalina González y don Yuçe de Soto habían surgido como consecuencia del arrendamiento de las rentas de los pontificales de Aranda de los años 1482-1483 y 1484. Catalina González, por su parte, alegaba que el arrendamiento de las rentas de los pontificales de Aranda de los años 14821483 había sido hecho de forma mancomunada por don Yuçe de Soto y por su mujer doña Bienvenida, por lo que ésta también era responsable; asimismo la acusaba de haberse llevado a la villa de Roa todos los bienes muebles que ella y su marido tenían en sus casas de Aranda, sin duda con el fin de evitar un embargo judicial de los mismos. Finalmente, la justicia regia falló en favor de doña Bienvenida, ordenando su puesta en libertad, así como que se le devolvieran todos los bienes que le habían sido embargados y que ella pudiera demostrar por contratos públicos que le habían sido entregados por su marido en concepto de dote y arras; del mismo modo, los alcaldes de Ararida de Duero García de Salazar, Juan Sánchez de Aranda el Mayor y Pearo Sánchez Centeno, fueron condenados en costas y obligados a pagar a doña Bienvenida la cantidad de 3.187 maravedíes, por el incumplimiento de una carta anterior del Consejo Real en la que se ordenaba su puesta en libertad ${ }^{17}$.

Dos años después, en septiembre de 1487, doña Bienvenida acudía nuevamente al Consejo Real quejándose en esta ocasión de que la sentencia anterior había sido respetada por los alcaldes de la villa de Aranda de

17 A.G.S., R.G.S., fols. 108, 72 y 39; documentos de 18 de abril de 1485 (Apéndice documental, núm. 3), 27 de abril de 1485 y 28 de junio de 1485, respectivamente. 
Duero, pero no por el alguacil Aparicio de Gormaz. Éste, con el fin de hacerse con unas casas «prinçipales» que doña Bienvenida tenía en esta localidad, y que lindaban con una casa suya, entró en tratos con ciertos acreedores de don Yuçe de Soto - en concreto con el recaudador real Juan de Figueroa-, con el fin de que estas casas y unas viñas también pertenecientes a este judío fuesen rematadas en pública almoneda para, de este modo, resarcirse de las deudas que con ellos tenía. Pero el alguacil se había apropiado de estas casas $y$, tras su muerte, permanecian en posesión de su viuda, sin que ni uno ni otra hubieran satisfecho con ellas a los acreedores de don Yuçe de Soto. Asimismo se quejaba doña Bienvenida de que, estando su marido en prisión, hubo de dar en prenda al aposentador real Diego de Valladolid unas casas, con su bodega y diez cubas de vino, que podrían valer en conjunto unos setenta mil maravedíes, en compensación por los veinte mil maravedíes que le debía don Yuçe de Soto; y sin que se hubieran cumplido los plazos para hacer efectiva la deuda, Juan de Cuero, alguacil de Aranda de Duero, las había vendido y rematado en pública almoneda, por valor de veinte mil maravedies. Estas casas fueron adquiridas por Catalina González, quien posteriormente las traspasó al provisor y receptor de la diócesis de Osma por cuarenta y siete mil maravedíes. Doña Bienvenida alegaba que el consentimiento dado en su momento para que se procediera a la almoneda no era válido, pues se había hecho estando preso su marido, y que, además, los bienes embargados se habían vendido por menos de la mitad del justo precio y se habían traspasado a persona eclesiástica, con quien ella no podría alcanzar cumplimiento de justicia. Por todo ello, doña Bienvenida reclamaba la devolución de estas casas, con sus correspondientes esquilmos. Como es habitual en estos casos, la justicia regia comisionó al corregidor de Aranda para que viera el asunto y actuara con arreglo a justicia ${ }^{18}$.

Parece muy probable que, en relación con este asunto, se planteara una pugna entre jurisdicciones - real y eclesiástica-, tan frecuente en época medieval, pues en junio de 1489 el condestable don Pedro Fernández de Velasco se dirigía a don Juan Sánchez de Torquemada, arcediano de Haza ${ }^{19}$ y provisor y vicario general de la iglesia y del obispado de Osma, para que le enviara el proceso que había llevado contra los alcaldes de la villa de Aranda de Duero, con el fin de determinar si el asunto tratado era competencia de la jurisdicción real o de la episcopal. Doña Bienvenida se habia quejado ante las justicias regias por la intromisión

18 A.G.S., R.G.S., fol. 25; documento de 6 de septiembre de 1487. Apéndice documental, núm. 4.

19 Localidad burgalesa situada a unos 13 kilómetros al oeste de Aranda de Duero. 
del provisor de la diócesis de Osma en el pleito que ella estaba tratando, ante los alcaldes de la villa de Aranda de Duero, en relación con unas casas que eran propiedad de ella y de su marido en el barrio arandino de San Juan; según exponía esta judía, los alcaldes ya habían cumplimentado la toma de pruebas a las dos partes litigantes, pero la parte contraria, consciente de su falta de razón, había acudido ante el provisor logrando que diera carta inhibitoria para los alcaldes de Aranda, so pena de excomunión. Doña Bienvenida alegaba que se trataba de una causa profana y entre legos, y que el pleito estaba pendiente ante los alcaldes de Aranda desde hacía ya un año y medio, por lo que no procedía la intromisión de la justicia eclesiástica ${ }^{20}$.

Entre tanto, don Yuçe de Soto había reaccionado también contra su detención, que consideraba ilegal. Así, se quejaba de que hacía varios años, encontrándose retenido en la localidad de Torregalindo ${ }^{21}$, con ocasión de las diferencias que mantenía con el recaudador real Juan de Figueroa y con el provisor de la diócesis de Osma, había recibido una carta de seguro para trasladarse a Aranda, con el fin de tratar de llegar a un acuerdo con sus contrarios. Pero esta carta de seguro no habría sido respetada, de forma que fue detenido en Aranda, manteniéndosele preso durante cuatro años ${ }^{22}$, período en el que le habrían provocado unos gastos de más de mil doblas de oro ${ }^{23}$. Asimismo se quejaba de que le habían tomado siete mil cántaras de vino que tenía en Aranda de Duero, vendiéndolas en su mayor parte por menos del valor de su justo precio. Mil quinientas de estas cántaras las tenía depositadas en casa del escribano Pedro García Daza, como prenda del préstamo de diez mil quinientos maravedíes que éste le había facilitado ${ }^{24}$. Éste, enterado de que estaba preso don Yuçe de Soto, habría tomado las llaves de la bodega donde se encontraban las cántaras a Juan Puento, hacedor ${ }^{25}$ de don Yuçe, y habría procedido a vender el vino contra su voluntad, sin previa autorización de

\footnotetext{
20 A.G.S., R.G.S., fol. 167; documento de 2 de junio de 1489.

21 Pequeña población burgalesa situada a pocos kilómetros al suroeste de Aranda de Duero.

22 Se trata, sin duda, de un cómputo equivocado, pues el documento es de septiembre de 1487, y no consta que don Yuçe de Soto estuviera preso desde 1483.

${ }^{23}$ Pese a la exageración interesada de esta cifra, es suficientemente elocuente de la capacidad económica de don Yuçe de Soto.

La dobla de la banda castellana equivalía a fines del siglo $x v$ a 365 maravedíes, por lo que la suma supuestamente gastada por don Yuçe de Soto ascendería a 365.000 maravedíes (Miguel Ángel LADERO QUESADA, La hacienda real castellana entre 1480 y 1492 . Universidad de Valladolid, 1967, pág. 22).

24 Cabe suponer que los diez mil quinientos maravedíes sería el precio de las mil quinientas cántaras de vino (a razón de siete maravedíes cada cántara), menos cierto porcentaje que correspondería al interés que llevaría aparejado el préstamo.

25 Es decir, el administrador de su hacienda.
} 
juez $o$ alcalde, y sin que hubieran transcurrido aún los plazos fijados para la devolución del préstamo. Asimismo se quejaba don Yuçe de Soto de que Pedro García Daza le debía la cantidad de cuarenta y cinco mil seiscientos maravedíes por una obligación que con él tenía al tiempo que fue hecho preso, y que, sin haber acabado de satisfacérsela, le había sido entregada dicha obligación al deudor. Como respuesta a esta demanda, el Consejo comisionó al corregidor y al juez de la villa de Aranda para que vieran estas denuncias y actuaran con arreglo a derecho ${ }^{26}$.

Otro destacado miembro de la familia Soto, hermano de don Yuçe, era Yuda de Soto, también vecino de Aranda de Duero, y dedicado asimismo al arrendamiento de rentas. En el año 1481 tenía arrendadas ciertas rentas reales, que no es posible especificar, y por las que debía al recaudador real Juan de Figueroa algo más de cien mil maravedíes, motivo por el que se encontraba en prisión desde hacía más de dos años. Ante la queja de Juan de Figueroa de que no conseguía que se le hiciera justicia en la villa de Aranda, el Consejo Real acordó examinar el asunto, a cuyo fin ordenó el traslado de Yuda de Soto desde la prisión en que se encontraba ${ }^{27}$.

Otro hermano de don Yuçe de Soto era don Simuel de Soto, al que ya se ha hecho referencia anteriormente como un destacado miembro de la aljama arandina. Éste había prestado la cantidad de veintidós mil maravedíes a Francisco de Peñafiel, también vecino de Aranda de Duero. Transcurridos los plazos para satisfacer la deuda, Francisco de Peñafiel alegaba que no podía pagarla sin que se produjera un grave quebranto para su hacienda, proponiendo liquidarla mediante la entrega al judío acreedor de ciertos bienes raíces de su propiedad. Según decía, si se procediera a la venta de sus bienes para satisfacer su deuda perderia mucho, ya que no se le pagaría por ellos ni la tercera parte de su valor real, debido a que los vecinos de Aranda estaban sometidos al pago de muy elevados tributos a la hacienda regia (probablemente destinados a la guerra de Granada). La solicitud de Francisco de Peñafiel fue aceptada, por lo que se ordenó el nombramiento de dos personas, propuestas una por cada una de las partes, que deberían tasar sus bienes y tomar de ellos la parte correspondiente a los veintidós mil maravedíes de deuda ${ }^{28}$.

La documentación ofrece también noticias sobre rabi Ça, hijo de don Simuel de Soto, quien hizo un préstamo de ciertas cantidades de pan y

26 A.G.S., R.G.S., fol. 191; documento de 7 de septiembre de 1487. Apéndice documental, núm. 5.

27 A.G.S., R.G.S., fol. 32; documento de 30 de agosto de 1485.

28 A.G.S., R.G.S., fol. 213; documento de 29 de agosto de 1489. 
vino a dos vecinos de Aranda, Martín Sebastián y Pedro Cortés, por lo que éstos le debían la suma de dos mil trescientos maravedíes. Cumplido el plazo fijado en el contrato de préstamo, los deudores alegaban que no les era posible hacer frente al mismo sin grave quebranto en sus haciendas, por cuanto se encontraban en estado de gran pobreza, en tanto que rabí Ça era "onbre rico e cabdaloso», como se había demostrado por una información practicada por el Consejo Real, por lo que no le suponía ningún perjuicio un aplazamiento. El Condestable de Castilla ordenó que una tercera parte de la deuda fuera satisfecha inmediatamente, concediendo una prórroga de seis meses para las otras dos terceras partes, para lo que habrían de presentar fiadores ${ }^{29}$.

La promulgación del edicto de expulsión general de 31 de marzo de 1492 alteró considerablemente la normal actividad de los distintos integrantes de la familia Soto quienes, al parecer, optaron mayoritariamente por la salida del reino. Un documento de mayo de 1492 ilustra claramente una situación que debió ser habitual en relación con los contratos de préstamo cristiano-judíos una vez que se hizo público el edicto de expulsión. Así, don Simuel de Soto y sus hijos rabi Simuel y rabí Aby pusieron en conocimiento de las justicias regias que, desde el momento en el que se hizo pública la orden de expulsión de los judíos, ciertos acreedores suyos les apremiaban para que pagaran las deudas que con ellos tenían, aunque los plazos aún no hubieran vencido; por el contrario sus deudores, tanto de la villa de Aranda de Duero como de otros diversos lugares de la comarca, no les pagaban lo que les debían. Por este motivo, ellos no podían satisfacer sus deudas, ya que, además, los acreedores se negaban a recibir en pago por las deudas que con ellos tenían obligaciones y cartas de deuda en las que dichos judíos aparecían como acreedores. Don Simuel de Soto y sus hijos no tenían duda acerca de cuál era el objetivo que perseguían sus deudores y sus acreedores: teniendo en cuenta la inmediatez del plazo fijado para que abandonaran el reino los judíos que no se convirtieran al cristianismo, los primeros pretenderían que llegara la fecha de su salida del reino sin haberles satisfecho las deudas, en tanto que los acreedores aspirarían a hacerse con sus bienes por mucho menos de su valor real. En estas circunstancias, y dado lo extraordinario del caso, don Simuel de Soto y sus hijos solicitaban que se les autorizara a reclamar el cumplimiento de las cartas de deuda que con ellos tenían algunos cristianos aunque aún no hubieran vencido los plazos, a cuyo fin habría de nombrarse un ejecutor, y que sus acreedores fueran compelidos a aceptar en compensación por las deudas que con ellos tenían

\footnotetext{
29 A.G.S., R.G.S., fol. 337; documento de 21 de diciembre de 1490.
} 
otras obligaciones en las que ellos figuraban como acreedores; asimismo solicitaban que no se les obligara a satisfacer ninguna deuda hasta tanto a ellos no les pagaran las que se les debian.

La sentencia del Consejo Real será la habitual en este tipo de pleitos: se comisiona al bachiller Alfonso de Torres, vecino de Aranda de Duero, para que, tras estudiar el caso, nombrara a dos personas, una a propuesta de cada una de las partes, que tasaran los bienes muebles y raíces de don Simuel de Soto y de sus hijos, que habrían de ser aceptados por los acreedores como compensación de las deudas que con ellos tenían. Asimismo se concedía a éstos carta de seguro, tanto para sus personas como para sus bienes, para los tres meses que mediaban hasta su salida del reino ${ }^{30}$.

Con posterioridad se quejaron don Simuel de Soto y sus hijos rabí Ça y rabí Mose de que en algunas reclamaciones presentadas ante el bachiller Alfonso de Torres éste había actuado por vía ordinaria, y no por vía de ejecución, pese a que ellos le habían presentado obligaciones y contratos en los que ya habían vencido los plazos y que, además, llevaban aparejada ejecución; se quejaban también de que en alguna ejecución llevada a cabo por el mismo bachiller se había dado un nuevo plazo de treinta días y de que hacía otras «luengas e dilaçiones», de forma que llegaría el tiempo de abandonar el reino sin que hubieran podido cobrar lo que se les debía. Por otra parte, manifestaban que tenían en su poder muchas prendas de diversos deudores de la comarca, y que aunque habían hecho pregonar que fueran a retirarlas pagando las cantidades correspondientes, que no querían hacerlo, con la finalidad de reclamárselas mediante pleito en el momento que abandonaran el reino. El Consejo Real ordenó al bachiller Torres que procediera a ejecutar en bienes de los deudores las obligaciones y contratos en los que ya hubieran vencido los plazos: a fin de que no se produjeran dilaciones en la ejecución, los bienes muebles deberían ser vendidos en plazo de tres días y los raíces en plazo de nueve días. Asimismo el bachiller Torres, que es nombrado juez para todas las causas de estos judíos, debería proceder a vender todas las prendas que tuvieran éstos en su poder, de forma que en el momento de su partida del reino no se les hiciera ningún tipo de reclamación ${ }^{31}$.

En otras ocasiones eran los judícs los deudores, y se les acusaba por parte de los acreedores cristianos de dar largas en el cumplimiento de sus

30 A.G.S., R.G.S., fol. 331; documento de 8 de mayo de 1492. Apéndice documental, doc. núm. 6.

31 A.G.S., R.G.S., fol. 524; documento de 22 de mayo de 1492. Apéndice documental, núm. 9. 
obligaciones contractuales con el fin de que, entre tanto, llegara la hora de la partida. Éste es el caso de don Yuçe de Soto, quien debía a Garci Sánchez de Calahorra y a sus hermanos la suma de veinte mil maravedíes y una taza de plata que valía marco y medio y dos onzas, así como otros dos mil quinientos maravedíes; y a García de Quemada treinta y seis mil maravedíes, por los que le hipotecó unas casas que tenía en el barrio arandino del Cascajal. En ambos casos alegaba que no poseía hacienda con la que hacer frente a las deudas, por cuanto los bienes que poseía eran de sus hijos, ya que pertenecían a la dote de su mujer ${ }^{32}$.

La importancia de la familia Soto se deduce también de la comisión dada por el Consejo Real al bachiller Alonso de Torres para que acompañara a don Simuel de Soto, y a sus criados, amigos y parientes judíos de la villa de Aranda de Duero hasta su salida del reino, con el fin de que les fuera guardada la carta de seguro otorgada por los reyes con carácter general a todos los judíos que optaran por el exilio ${ }^{33}$. En otro pasaje de la misma carta se indica que Alonso de Torres acompañaría a los judíos de la villa de Aranda que salieran del reino, lo que es indicativo de que la marcha hacia la frontera se hizo con los judíos de cada población —o de varias poblaciones- agrupados, y generalmente acompañados por una persona comisionada por el Consejo Real. Es muy probable que don Simuel de Soto fuera la máxima autoridad de la aljama de Aranda de Duero y que, en funciones de representación de la misma, reclamara el seguro regio para todos los judíos que tomarían el camino hacia la frontera del reino de Castilla (hacia Portugal, con toda probabilidad). La carta de comisión al bachiller Torres tenía por objeto que éste protegiera las personas y los bienes de los judíos, impidiendo que les fueran reclamados «portadgos e viajes e castillerías e diezmos e pontajes" por los bienes que transportaban; que les prohibieran la entrada en ciudades, villas y lugares por las que atravesaran; y que les impidieran hospedarse en posadas y mesones o comprar alimentos y otras cosas necesarias para el viaje (bestias y carretas) a precios razonables.

De las mismas fechas se conserva una carta de comisión del Consejo Real a Juan de Ribera, vecino de Valladolid, y al bachiller Alonso de Torres, para que vieran todos los contratos y obligaciones que tenían rabí Yuda, su hermano Yuçe de Soto, Simuel de Soto, Sycorro, Haze y Simuel de Soer, vecinos de Gumiel de Mercado, en esta villa y en otros lugares de su

\footnotetext{
32 A.G.S., R.G.S., fols. 657 y 510; documentos de 17 de mayo y de 22 de mayo de 1492 , respectivamente. Apéndice documental, núms. 7 y 8 .

33 A.G.S., R.G.S. fol. 526; documento de 22 de mayo de 1492. Luis SuÁREZ FERnÁndeZ, Documentos acerca de la expulsión de los judios, págs. 408-411.
} 
comarca (Val de Esgueva, Ventosilia, la Horra, Aguilera). En esta carta se ordena que se procediera a ejecutar en bienes de los deudores todos aquellos contratos que llevaran aparejada ejecución y cuyos plazos ya hubieran vencido, y que en todos los demás se hiciera breve cumplimiento de justicia. Por lo que respecta a las deudas que estos judíos tenían con otras personas, quedarían saldadas mediante el traspaso a los acreedores de obligaciones liquidas que fueran de los mismos plazos y cantidades ${ }^{34}$.

En otra carta, el Consejo Real se dirigía a las autoridades de las villas de Gumiel de Mercado y Gumiel de Izán y les ordenaban que no se pusieran impedimentos a rabí Yuda, a su hermano Yuçe de Soto, a Simuel de Soto, a Socorro, a Haze y a Simuel Soer, vecinos de Gumiel de Mercado, para la venta de sus bienes. Al parecer, algunas personas extendian interesadamente el rumor de que los reyes habían prohibido la compra de los bienes de los judíos, a fin de que se marcharan sin haber podido venderlos $y$, de este modo, hacerse con ellos ${ }^{35}$.

Los pleitos con motivo de los bienes y de los contratos de deuda de los judios prosiguieron tras su salida del reino, de forma que en noviembre de 1494 los Alcaldes de Casa y Corte dieron una carta de emplazamiento para Diego de Arlanzón, receptor real, y para Alonso del Castillo, juez comisario en el Obispado de Osma para los bienes y deudas que los judíos dejaron al tiempo de su salida del reino, en relación con una sentencia que habían dado acerca de ciertos bienes que Juan de Bonilla, Martín Sánchez de Villarreal, Juan Brazo y Martín Seco, vecinos de Aranda de Duero, habian comprado a don Simuel de Soto, y que en virtud de dicha sentencia fueron adjudicados a la Cámara y fisco real, probablemente a causa de alguna deuda que este judío tendría con la hacienda regia ${ }^{36}$.

En febrero de 1495 el Consejo Real dio carta de comisión a Alonso del Castillo, juez de los bienes que dejaron los judíos del Obispado de Osma, para que viera la queja formulada por Juan Núñez de Calahorra, vecino de Aranda de Duero. Alegaba éste que al tiempo de la salida de los judíos del reino había puesto una demanda contra don Simuel de Soto, por cuantía de veinte mil maravedies, por unas casas y una bodega que le había llevado por una deuda con logro, consiguiendo que fuera hecho preso. En estas difíciles circunstancias, don Simuel de Soto acordó con Juan Núñez de Calahorra y con Juan Prieto, vecinos de Aranda, que éstos se harian cargo

A.G.S., R.G.S., fol. 531; documento de 24 de mayo de 1492. Apéndice documental, núm. 10.

35 A.G.S., R.G.S., fol. 532; documento de 24 de mayo de 1492. Luis SUÁREZ FERNÁNDEZ, Documentos acerca de la expulsión de los judios, págs. 414-416.

36. A.G.S., R.G.S., fol. 468; documento de 29 de noviembre de 1494. 
de las deudas que él pudiera tener, concediéndoles a cambio las escrituras de contratos de deuda que él tenía en la villa de Aranda de Duero y en su comarca, $y$ en los que era acreedor por un total de ciento sesenta mil maravedies. Posteriormente, Alonso del Castillo se había hecho con las escrituras de don Simuel y procedía a hacerlas efectivas, sin pagar a Juan Núñez de Calahorra ni siquiera las cantidades que le adeudaba aquél ${ }^{37}$.

Aunque no se conservan noticias al respecto, lo más probable es que la familia judía de los Soto, o al menos la mayor parte de sus integrantes, pasara en 1492 a Portugal. La ausencia de cualquier tipo de informaciones acerca de un posible retorno a Castilla hace suponer que el exilio de esta familia debió ser definitivo - posiblemente en el norte de África, al menos en un primer momento-, pues ninguna noticia se ha conservado sobre la reclamación de bienes por parte de alguno de sus miembros tras un hipotético regreso a sus lugares de origen -Aranda de Duero, Roa, Gumiel de Mercado-, lo que fue hasta cierto punto bastante frecuente en numerosas localidades castellanas entre 1493 y 1499, aprovechando las cartas de seguro concedidas por los Reyes Católicos a todos aquellos judíos que regresaran convertidos previamente al cristianismo ${ }^{38}$.

\section{APÉNDICE DOCUMENTAL}

1485, marzo 9

Carta a las autoridades de las villas de Roa, Peñafiel y Cuéllar para que prendan a don Yuça de Soto, judío vecino de Aranda de Duero, y lo entreguen a Aparicio de Gormaz, alguacil de esta villa.- Consejo Real.

A.G.S., R.G.S., fol. 102, III-1485.

Don Fernando e doña Ysabel, e çetera. A los alcaldes de la nuestra Casa e Corte e Chançellería, e a todos los corregidores, e asystentes, alcaldes e otras justiçias e juezes qualesquier, asy de las villas de Roa e Peñafiel e Cuéllar commo de todas las çibdades e villas e logares de los nuestros reynos e señoríos, e a vos Pedro de Aranda, nuestro escribano, al

\footnotetext{
37 A.G.S., R.G.S., fol. 492; documento de 16 de febrero de 1495. Apéndice documental, núm. 11.

38 Luis SUÁREZ FERNÁNDEZ, Documentos acerca de la expulsión de los judíos, págs. 59-60. Véase también mi breve trabajo "Judios de Torrelaguna: retorno de algunos expulsados entre 1493 y 1495», en Sefarad, XXXIX (1979), págs. 333-346.
} 
qual nos fazemos nuestro mero esecutor para lo en esta carta contenydo, e a cada uno de vos a quien esta nuestra carta fuere mostrada, salud e graçia. Sepades que Aparisçio, alguazyl e veçino de la villa de Aranda, nos fizo relaçión quél tenya preso en la cárçel pública de la dicha villa de Aranda a don Yuça, judío, por çiertas debdas que devya a çiertas personas veçinos de la dicha villa de Aranda e de otras partes. El qual diz questovo preso en la dicha cárçel asaz tienpo, fasta que se fue della de noche, e quebró las cadenas e presyones donde estava, e se fue fuyendo de la dicha cárçel. E diz questá reçetado e acogido en alguna parte donde non puede ser avido, commo quier quél ha fecho sobrello muchas diligençias. E diz que las personas a quien devya las dichas debdas dizen que les dé al dicho judío o les pague lo que les devya. Sobre lo qual nos mandamos resçebir ynformaçión e, vista en el nuestro Consejo, mandamos dar nuestra carta para vos, las dichas justiçias, que luego prendiésedes el cuerpo al dicho judío e lo entregásedes preso al dicho Aparisçio, alguazyl, para que lo levase a la dicha villa de Aranda e lo tovyese preso en la cárçel della donde asy se soltó. Con la qual dicha carta diz que requerió al liçençiado Diego de Álava, alcalde en la dicha villa de Cuéllar. El qual diz que aunque le podiera entregar el dicho judío non lo quiso fazer, antes diz que dio logar quel dicho judío se sobiese a la fortaleza de la dicha villa de Cuéllar, en tal manera que a cabsa e culpa del dicho alcalde non pudo aver al dicho judío. E diz que sobrello le fatigan al dicho alguazil los acreedores, pidiéndole ante los juezes de la yglesia sobre lo suso dicho, e ante nuestras justiçias. En lo qual todo diz que sy asy pasase, él resçebiría mucho agravio e daño. E dezía quel dicho liçençiado, allende de pagarle todas las dichas debdas del dicho judío e a sacarle a paz e a salvo al dicho alguazil de todo ello. Por ende, que nos suplicava que le mandásemos proveer de justiçia sobrello, por tal manera quél non resçebiese daño nin se le recreçiesen más costas nin daños. Sobre lo qual nos mandamos resçebir informaçión en el nuestro Consejo. E vista, fue acordado que devyamos mandar dar esta carta en la dicha razón. Por que vos mandamos a todos e a cada uno de vos en vuestros logares e jurediçiones, e a vos el dicho Pedro de Aranda, nuestro esecutor, que donde quier e en qualquier logar que falláredes al dicho Yuça, judío, luego le prendades el cuerpo. E preso en buen recabdo lo entreguedes al dicho Aparisçio, alguazil, o a quien su poder para ello oviere, para que lo pueda levar e lleve preso a la dicha villa de Aranda e le pongan en la cárçel de la dicha villa donde se soltó, por tal manera quel dicho Aparisçio, alguazil, non sea más fatygado nin resçiba costas nin daños sobre lo suso dicho. E sy para lo asy fazer e conplir e esecutar oviéredes mester favor e ayuda, por esta carta mandamos a todos los que son corregidores, alcaldes, regidores, cavalleros e escuderos, ofiçiales e omes buenos desas dichas çibdades e villas e logares, e a cada una dellas que sobrello por 
vos o por qualquier de vos fueren requeridos, e a cada uno dellos e a qualesquier nuestros vasallos e súbditos e naturales, de qualquier estado o condiçión que sean, a cada uno dellos que vos den e fagan dar para lo suso dicho e cada cosa e parte dello todo el favor e ayuda que les pidiéredes e mester oviéredes. $E$ que vos non pongan nin consyentan poner en ello nin en parte dello enbargo nin contrario alguno, so las penas que vos o qualquier de vos les posierdes, las quales les ponemos por la presente. Para lo qual todo que dicho es e cada cosa dello, con todas sus inçidençias e dependençias e conexidades, damos poder conplido a vos, el dicho nuestro esecutor, por esta nuestra carta. $E$ non fagades ende al, so pena de la nuestra merçed, e de diez mill maravedíes para la nuestra Cámara. E demás, mandamos a qualquier escrivano público que para esto fuere llamado que dé ende al que vos la mostrare testimonio synado con su signo, por que nos sepamos en cómmo se cunple nuestro mandado. Dada en la villa de Valladolid, a nueve días del mes de março, año del nasçimiento de nuestro Salvador lhesu Christo de mill e quatroçientos e ochenta e çinco años. E por esta carta damos poder e facultad al dicho Aparisçio de Gormaz para prender al dicho Yuça, judío, donde quier que lo fallare, e lo entregue a la justiçia del logar donde lo prendiere, para que la tal justiçia, por vertud desta carta, ge lo entreguen. Don Alonso Enrríquez, almirante de Castilla, por vertud de los poderes que tiene del rey e de la reyna, nuestros señores, la mandó dar, con acuerdo de los del su Consejo. Yo, Alfonso de Alcalá, escrivano de Cámara del rey e de la reyna, nuestros señores, la fiz escrivir con acuerdo de los del Consejo de su alteza. El almyrante. Garsías, liçençiatus. Gundisalvus, doctor.

Carta de emplazamiento al corregidor y a los alcaldes de la villa de Roa en el pleito que mantenía Juan de Figueroa con don Yuça de Soto, judío vecino de Aranda de Duero.- Consejo Real.

A.G.S., R.G.S., fol. 105, III-1485.

Don Fernando e doña Ysabel, e çetera. A vos el corregidor e alcaldes de la villa de Roa y a cada uno de vos, salud e graçia. Sepades que Juan de Figueroa, nuestro recabdador, nos fizo relaçión que don Yuça de Soto, judío vezino de la villa de Aranda, le deve çiento e diez mill maravedíes, poco más o menos, de las terçias de la dicha villa de Aranda y su tierra, que dél tovo arrendadas los años pasados de ochenta y uno y ochenta e dos años de quél fue nuestro recabdador. E diz quel dicho don Yuça de Soto, judío, él le 
tovo preso e se fue del poder del alguazil de la dicha villa de Aranda, segund que ante nos el traya pleito con el dicho alguazil. E diz que a su notiçia es venido quel dicho don Yuça de Soto tyene çiertos bienes muebles en esa dicha villa, los quales diz que el dicho alguazil tyene enbargados. E diz quél le pidió e requirió que pediese los dichos bienes para en pago de la dicha debda. Por ende, que nos suplicava que le mandásemos dar nuestra carta para vos, las dichas justiçias, para que vendiésedes los dichos bienes, e de los maravedíes que valiesen le entregásedes para en pago de lo que asy le es devido por el dicho Yuça. El qual dicho pedimiento fizo ante nos, con protestaçión de non se partyr del dicho pedimiento que tenya fecho al dicho alguazil, e que en manera alguna non lo feziese por juyzio, o que sobre ello le mandásemos proveer commo la nuestra merçed fuese. E nos tovímoslo por bien, por que vos mandamos que luego veades lo suso dicho. E llamadas e oydas las partes a quien tañe, lo más brebemente que ser pueda, non dando lugar a luengas de maliçia, fagades y administredes al dicho Juan de Figueroa, nuestro recabdador, sobre lo suso dicho conplimiento de justiçia, por tal manera quél la aya e alcançe, e por defeto della non aya cabsa nin razón de se más quexar sobre ello. E non fagades ende al, so pena de la nuestra merçed e de diez mill maravedíes para la nuestra Cámara. E de más, mandamos al omme que vos esta carta mostrare, que vos enplaze que parescades ante nos en el nuestro Consejo, del día que vos enplazare fasta quinze días primeros syguientes. So la qual dicha pena, mandamos a qualquier escrivano público que para esto fuere llamado, que dé ende al que vos la mostrare testimonio sygnado con su sygno, por que nos sepamos en cómmo se cunple nuestro mandado. Dada en la villa de Valladolid, a catorze días del mes de março, año del nasçimiento de nuestro Señor lhesu Christo de mill e quatroçientos e ochenta e çinco años. El almirante don Alfonso Enrríquez, almirante de Castilla, por vertud de los poderes que tiene del rey e de la reyna, nuestros señores, la mandó dar. Yo, Alfonso de Alcalá, escrivano de Cámara de su alteza, la fize escrivir con acuerdo de los del Consejo de su alteza. Garsyas, liçençiatus. Gundisalvus, doctor. Alfonsus, dottor.

1485 , abril 18

Carta a los alcaldes de la villa de Aranda de Duero para que suelten a doña Bienvenida, mujer del judío don Yuçe de Soto, de la prisión en que la tenían, o para que comparezcan ante el Consejo.- Consejo Real.

A.G.S., R.G.S., fol. 108, IV-1485. 
Don Fernando e doña Ysabel, e çetera. A vos los alcaldes de la villa de Aranda, e a cada uno de vos, salud e graçia. Sepades que por parte de doña Bienvenida, judía, muger de don Yuçe de Soto, judío vezino desa dicha villa, nos fue fecha relaçión quel dicho don Yuçe de Soto e Catelina Gonçález, muger que fue de Diego de Requena, vezina desa dicha villa, ovieron arrendado e arrendaron las rentas de los pontyficales desa dicha villa en el año pasado de ochenta e quatro. E que tenyendo asy arrendadas las dichas rentas, diz que la dicha Catelina Gonçález fezyera prender al dicho don Yuçe de Soto, por vertud de una carta de recurso del provisor del Burgo. E que estando asy preso el dicho don Yuçe en la cárçel pública desa dicha villa, diz que fuyera e se absentara de la dicha cárçel. E que por la dicha cabsa vosotros, a ynstança e pedimiento de la dicha Catelina Gonçález, enbiárades en poz del dicho don Yuçe, e lo fiziérades prender en la villa de Cuéllar, e lo bolbiérades a la dicha cárçel e presyón en que primeramente estava. E diz que estando preso el dicho don Yuçe que vos, los dichos alcaldes, a pedimiento de la dicha Catelina Gonçález, injusta e non devidamente, la prendiérades e mandárades prender e la teníades presa desde dos meses a esta parte, non deviendo nin estando obligada a cosa alguna. E quel dicho provisor de la dicha villa del Burgo le avía enbargado e puesto en secrestaçión e de manifiesto todos sus bienes dotales, a pedimiento de la dicha Catelina Gonçález. E que commo quier que por ella e por su parte avíades seydo requeridos que la soltásedes de la dicha presyón, pues quella non devía cosa alguna, e que asymesmo avía enbiado requerir al dicho provisor que feziese alçar e quitar la dicha secrestaçión de los dichos sus bienes, que vosotros nin él non lo avíades querido nin queríades fazer, en lo qual avía resçibido e resçibía muy grand agravio e daño. Por ende, que nos suplicava e pedia por merçed que çerca dello le mandásemos proveer e remediar con justiçia, por manera quella fuese suelta e libre, e le fuesen tornados e restituidos los dichos sus bienes dotales que asy estavan enìargados e puestos en secrestaçión, e mandando asymesmo al dicho provisor que de aquí adelante, pues quella e la dicha Catelina Gonçález eran seglares e de nuestra jurediçión real, que non se entremetyesen más a conosçer de la dicha cabsa, so pena de perder las tenporalidades que en estos nuestros reynos avía e tenía, e sobre todo le proveyésemos commo la nuestra merçed fuese. Lo qual todo visto en el nuestro Consejo, fue acordado que nos devíamos mandar dar esta nuestra carta para vosotros en la dicha razón. E nos tovímoslo por bien, por la qual vos mandamos que luego que con ella fuerdes requeridos, soltedes e fagades soltar a la dicha doña Bienvenida, judía, de la dicha presyón que está, o dentro de seys días primeros siguientes que con ella fuerdes requeridos, enbiedes ante nos en el nuestro Consejo a 
dar razón e mostrar sufiçientemente por qué la tenedes presa, pues que diz que por debda del dicho su marido, a que ella non está obligada, non devió nin deve ser estar presa nin detenida. E aquesto fazer e conplir, por tal manera quella non resçiba agravio contra justiçia, nin por defeto della aya más cabsa nin razón de se nos venir nin enbiar a quexar sobre ello. $E$ non fagades ende al por alguna manera, so pena de la nuestra merçed e de diez mill maravedíes a cada uno de vos para la nuestra Cámara. E de más, mandamos al omme que vos esta nuestra carta mostrare, que vos enplaze que parescades ante nos, del día que vos enplazare fasta quinze días primeros siguientes. So la qual dicha pena, mandamos a qualquier escrivano público que para esto fuere llamado, que dé ende al que vos la mostrare testimonio sygnado con su sygno, por que nos sepamos cómmo cunplides nuestro mandado. Dada en la noble villa de Valladolid, a diez e ocho días del mes de abril, año del nasçimiento del nuestro Señor thesu Christo de mill e quatroçientos e ochenta e çinco años. El almirante don Alonso Enrríquez, almirante de Castilla, por vertud de los poderes que del rey e de la reyna, nuestros señores, tyene, la mandó dar. Yo, Juan Sánchez de Çehinos, escrivano de Cámara de sus altezas, la fyz escrivir con acuerdo de los del su Consejo. Gundisalvus, liçençiatus. Gundisalvus, dotor.

1487 , septiembre 6

Carta de comisión al juez o corregidor de Aranda, para que vea la demanda presentada por doña Bienvenida, mujer del judío don Yuçe de Soto, contra la actuación de los alguaciles de dicha villa.- Consejo Real.

A.G.S., R.G.S., fol. 25, IX-1487.

Don Fernando e doña Ysabel, e çetera. A vos el ques o fuere nuestro juez e corregidor en la villa de Aranda, salud e graçia. Sepades que Bienvenida, judía, muger de Yuçe de Soto, vezina de la villa de Roa, nos fizo relaçión por su petiçión, deziendo que por çiertas nuestras cartas le fueron mandados dar y entregar çiertos bienes, asy muebles con (sic) rayzes, quel dicho su marido tenía e poseya en la villa de Aranda para en pago del dotte que ella con él ovo traído e arras quél le ovo prometydo al tienpo que con ella casó. Con las quales dichas nuestras cartas e provisyones, junto con los contratos de dotte e arras que ella asy tyene contra el dicho su marido, diz que las justiçias de la dicha villa de Aranda fueron requeridos por su parte para que ge las conpliesen, segund que pasó por 
ante escrivano público. E diz que las dichas justiçias las obedesçieron e conplieron. E diz que después que Apariçio de Gormaz, alguazil que a la sazón hera en la dicha villa de Aranda, yendo e pasando contra el thenor e forma de las dichas nuestras cartas e provisiones, e a fyn de entrar a unas casas prinçipales quella tenía e poseya en la dicha villa de Aranda, linderos de una casa suya del dicho alguazil donde él vibía e morava, tovo formas e maneras con algunos acreedores del dicho su marido, espeçialmente con un Juan de Figueroa, recabdador, vezino de la noble çibdad de Toledo, que se fiziese esecuçión en las dichas casas e se rematasen en pública almoneda con çiertas viñas quel dicho su marido tenía en la dicha villa de Aranda, a fyn de se entrar en las dichas casas e quedarse con ellas el dicho alguazil, segund que diz que por la obra paresçió. Porque diz quel dicho alguazil, syn la parte, dio sacador para las dichas casas e viñas, e se entró en ellas, e las tovo, e poseó en su vida fasta que fallesçió. Las quales diz que agora tyene e posee la muger del dicho alguazil, e syn aver pagado a ninguno de los creedores. Por ende, que nos suplicava e pedía por merçed le mandásemos tornar las dichas casas e viñas, e defender e anpararla en la posesyón de todo ello, segund e por la forma e manera que en las dichas nuestras cartas e provisyones se contiene, porque diz que fueron dadas para en pago de su dote e arras, pues los dichos contratos diz que paresçía e paresçen ser su deuda devida en tienpo e mejor derecho, condepnándole asy mesmo en la pena de la fuerça e en las rentas e esquilmos de las dichas casas e viñas, desdel día en que las tyene tomadas e ocupadas contra su voluntad fasta oy. E otrosy diz que al tienpo quel dicho su marido estava preso, ella ovo de dar consentymiento por treynta mill maravedíes, poco más o menos, quel dicho su marido devía a Diego, posentador, vezino de la dicha villa de Aranda, que por los veynte mill maravedíes dellos toviese en prendas unas casas quel dicho su marido e ella tenían en la dicha villa de Aranda, con su bodega e diez cubas en ellas, que pueden valer más de setenta mile maravedíes. E diz que syn finitar el tienpo nin plazo a la paga de los dichos veynte mill maravedíes, Juan de Cuero, alguazil de la dicha villa de Aranda, diz que ge las vendió e remató en pública almoneda, por quantía de los dichos veynte mill maravedíes, poco más o menos. Las quales diz que sacó Catalina Gonçález, muger de Diego de Requena, vezina de la villa de Aranda, e las dió e traspasó luego en el provisor e reçebtor del obispado de Osma por quarenta e syete mill maravedíes, por les fazer perder su derecho e abçión que a las dichas casas tenía. E diz que en la ora misma quella dio el dicho consentimiento a las dichas casas, reclamó por ante escrivano por ser commo fue fecho el dicho su marido preso. E la liçençia quél asy le dio para en ello, sería e 
es en sy ninguna por se aver vendido commo fueron vendidas por menos de la mitad del justo preçio e valor, e por se aver traspasado e vendido a persona eclesyástica, con quien ella diz que non podría alcançar conplimiento de justiçia, la dicha Catalina Gonçález diz que abría e ha perdido qualquier derecho e avçión que a las dichas casas toviese. E por ende, que nos suplicava e pedía por merçed çerca dello le mandásemos proveer, mandándole bolver las dichas casas e cubas, con los esquilmos della, libres e desenbargadas, pues que todo lo fecho e esecutado fasta oy en ellas avía seydo e fue en su grand perjuizio, por ser commo diz que fue todo contra su voluntad. $E$ aviendo seydo por ella reclamado en tienpo e sazón, la mandásemos anparar e defender en la posesyón de todo ello, o la mandásemos prover çerca de todo ello commo la nuestra merçed fuese. E nos tovímoslo por bien. E confiando de vos que soys tal persona que guardaredes nuestro serviçio e el derecho a cada una de las partes, e bien e fiel e deligentemente fareys lo que por nos vos fuere encomendado, es nuestra merçed de vos encomendar e cometer, e por la presente vos encomendamos e cometemos, lo suso dicho. Por que vos mandamos que luego veades lo suso dicho e cada cosa dello, e llamadas e oydas las partes a quien atañe, brebemente e de plano, syn estrépitu e figura de juyzio, sabida sólamente la verdad, non dando logar a luengas nin dilaçiones de maliçia, libredes e determinedes en ello lo que fallardes por justiçia por vuestra sentençia o sentençias. Las quales e el mandamiento o mandamientos que en la dicha razón dierdes e pronunçiardes, lleguedes e fagades llegar a pura e devida esecuçión, con efeto quanto e commo con fuero e con derecho devades. E mandamos a anbas las dichas partes e a cada una dellas, $e$ a otras qualesquier personas de quien entendierdes ser ynformado e saber la verdad çerca de lo suso dicho, que vengan e parezcan ante vos a vuestros llamamientos e enplazamientos, a los plazos e so las penas que de nuestra parte les posyerdes. Las quales nos, por la presente, les ponemos e avemos por puestas. Para lo qual asy fazer e conplir e esecutar, vos damos poder conplido por esta nuestra carta, con todas sus ynçidençias, dependençias, e mergençias, anexidades e conexidades. $E$ non fagades ende al por alguna manera, so pena de la nuestra merçed. Dada en la muy noble çibdad de Burgos, a seys días del mes de setienbre, año del nasçimiento de nuestro Señor Ihesu Christo de mill e quatroçientos e ochenta e syete años. El condestable don Pero Fernández de Velasco, Condestable de Castilla, por vertud de los poderes que tiene del rey e de la reyna, nuestros señores, la mandó dar. Yo, Sancho Ruyz de Cuero, secretario de sus altezas, la fize escrivir, con acuerdo de los del su Consejo. Gundisalvus, liçençiatus. Sançius, doctor. Françiscus, doctor e abbas. 


\section{7, septiembre 7}

Carta de comisión al juez y corregidor de Aranda para que vea la queja de Yuçe de Soto, judío vecino de la villa de Roa.- Consejo Real.

A.G.S., R.G.S., fol. 191, IX-1487.

Don Fernando e doña Ysabel, e çetera. A vos el ques o fuere nuestro juez e corregidor en la villa de Aranda, salud e graçia. Sepades que Yuçe de Soto, judío vezino de la villa de Roa, nos fizo relaçión por su petiçión, dezyendo quél estando retenydo en Torregalindo, a cabsa de çiertas pendençias de cuentas que tenía con Juan de Figueroa, vezino de la noble çibdad de Toledo, e con el provisor del obispado de Osma. E diz que los sobredichos, e otras personas que con él tenían pendençias, le ovieron de dar seguro para quél fuese a la villa de Aranda para ver sy se podría conçertar con ellos. E diz quél fue a la dicha villa de Aranda con el dicho seguro, e diz que los que asy le dieron el dicho seguro, yendo e pasando contra él, le prendieron en la dicha villa e le han tenido preso çerca de quatro años, en que diz que le han fecho gastar más de mill doblas doro. Allende de lo qual, diz que le tomaron fasta syete mill cántaras de vino que tenía en la dicha villa de Aranda, de las quales diz que le fezyeron vender a malbarato la mayor parte dellas. De las quales diz que tenía en casa de uno que se llama Pero García Daça, escrivano, vezino de la dicha villa de Aranda, fasta mill e quinientas cántaras de vino, sobre las quales diz que le prestó el dicho Pero García Daça fasta diez mill e quinientos maravedíes, poco más o menos. E diz que commo le vio preso tovo manera commo tomó las llaves de la bodega donde estava el dicho vyno en su casa a un Juan Puento, su hazedor, e entró e tomó el dicho vyno e lo vendió por fuerça contra su voluntad, syn lo él saber, e syn liçençia de juez nin alcalde, e syn ser llegado el tienpo de la paga, por lo qual diz quel dicho Pero Garçía Daça perdió el derecho e abçión que al dicho vyno tenya, e yncurrió en muy grandes e graves penas çeviles e creminales. Por ende, que nos suplicava e pedía por merçed çerca dello con remedio de justiçia le mandásemos prover, mandando bolber el dicho vyno de la dicha forma, en manera quél e el dicho su fazedor lo tenían al tienpo que le prendieron. $\mathrm{E}$ asymismo le mandásemos pagar las costas e dapnos e menoscabos que se le han recreçido fasta oy desdel día que asy le han tenido preso, esecutando en ellos e en cada uno dellos las penas en tal caso estableçidas. E asymismo diz quel dicho Pero Garçía Daça le devía por una obligaçión quarenta e çinco mill maravedíes e seysçientos maravedíes, 
poco más o menos, la qual diz quél tenía en su poder al tienpo que le prendieron. E diz que agora es venido a su notiçia commo la dicha obligaçión vino a poder del dicho Pero Garçía Daça, syn ge la aver acabado de pagar. Por ende, que nos suplicava que la mandásemos bolver, segund que la él tenía en su poder, o mandásemos al escrivano por ante quien ovo pasado la dicha obligaçión, que la torne a sacar de su registro e que la dé synada en manera que faga fe, para quél pueda cobrar del dicho Pero Garçía e de sus byenes los maravedíes en ella contenidos, ca él está presto de le tomar e reçebir en cuenta todos los maravedíes que verdaderamente oviere pagado, o le mandásemos proveer çerca dello lo que la nuestra merçed fuese. E nos tovímoslo por bien, e confiando de vos que soys tal que guardaredes nuestro serviçio e el derecho a cada una de las partes, e bien e fielmente fareys lo que por nos vos fuere encomendado, es nuestra merçed de vos encomendar e cometer, e por la presente vos encomendamos e cometemos, lo suso dicho. Por que vos mandamos que luego veays lo suso dicho e cada cosa dello. E llamadas e oydas las partes a quien lo suso dicho toca e atapne, brevemente e de plano, syn estrépitu e figura de juyzio, sabida sólamente la verdad, non dando logar a luengas nin dilaçiones de maliçia, libredes e determinedes en ello todo aquello que fallardes por derecho por vuestra sentençia o sentençias, asy interlocutorias commo definity vas. Las quales e el mandamiento o mandamientos que en la dicha razón dierdes e pronunçiardes, lleguedes e fagades llegar a pura e devida esecuçión, con efetto, quanto e commo con fuero e con derecho devades. $E$ mandamos a las dichas e a cada una dellas, e a las dichas personas de quien entendierdes ser ynformado çerca de lo suso dicho, que vengan e parescan ante vos a vuestros Ilamamientos e enplazamientos, a los plazos e so las penas que les vos posierdes o mandardes poner de nuestra parte, las quales nos, por la presente, les ponemos e avemos por puestas. Para lo qual asy fazer e conplir e esecutar, vos damos poder conplido por esta nuestra carta, con todas sus ynçidençias, dependençias, e mergençias, anexidades e conexidades. $E$ non fagades ende al por alguna manera, so pena de la nuestra merçed e de diez mill maravedies para la nuestra Cámara. Dada en la muy noble çibdad de Burgos, a syete días del mes de setyenbre, año del nasçimiento de nuestro Señor lhesu Christo de mill e quatroçientos e ochenta e syete años. El condestable don Pero Fernández de Velasco, por vertud de los poderes que tiene del rey e de la reyna, nuestros señores, la mandó dar. Yo, Sancho Ruyz de Cuero, secretario de sus altezas, la fize escrivir, con acuerdo de los del su Consejo. Gundisalvus, liçençiatus. Sançius, doctor. Françiscus, dottor e abbas. 
1492, mayo 8

Carta de comisión al bachiller Torres para que vea la queja presentada por don Simuel de Soto y sus hijos, en relación con los contratos de préstamo que tenían con cristianos vecinos de la villa de Aranda de Duero y de otros lugares de la comarca.- Consejo Real.

A.G.S., R.G.S., fol. 331, V-1492.

Don Fernando e doña Ysabel, e çetera. A vos el bachiller de Torres, vezino de la villa de Aranda, salud e graçia. Sepades que por parte de don Simuel de Soto, e de rabí Simuel e de rabí Aby, sus fijos, nos fue fecha relaçión por una petyçión que en el nuestro Consejo fue presentada, diziendo quellos han tenido tratos de mercaderías, asy con christianos commo con judíos, e que a algunos dellos, por hazer buena, les avían prestado muchas quantyas de maravedíes, asy en la dicha villa commo en otros muchos logares comarcanos, e quellos asymismo deven a las tales personas algunas quantyas de maravedíes. E que los plazos dellas algunos son llegados e otros non, e que son mucho fatygados por los crehedores para que les paguen, aunque los plazos non son llegados, lo qual ellos non podían pagar sy non cobrasen primero las debdas que les heran, lo qual ellos non podían fazer a causa que nos mandáramos publicar e apregonar en todas las çibdades e villas e logares destos nuestros reygnos e señoríos que dentro de tres meses, contados desde el día de casymodo que agora pasó, todos los judíos saliesen destos nuestros reygnos donde moravan y estavan, so grandes penas. E que en las cartas e provisiones mandáramos dar e diéramos e tomáramos a los dichos judíos e a sus bienes so nuestro seguro y anparo. $\mathrm{E}$ diz quellos han escomençado a pagar e pagan algunas debdas de las que deven, e sus debdores diz que non les han querido nin quieren pagar lo qual les deven, asy por obligaçiones commo en otra manera, nin quieren tanpoco resçibir en pago sus crehedores algunas obligaçiones e çiertas debdas que ellos tienen en otras personas, porque piensan sus debdores e crehedores, los unos de non les pagar lo que les deven, e los otros que les entiende dar e tomar su fazienda e bienes en el presçio que quesieren e commo quesieren, viendo e sabiendo la brevedad del dicho tienpo en que los dichos judíos han de salir destos nuestros reygnos. E que pues el término hera tan breve e ellos tenían tanta nesçesidad e obligaçión de penas para cunplir el dicho nuestro mandamiento, e se avían de ausentar de los dichos sus debdores syn poder después tornar a entrar en estos nuestros reygnos a demandarles que les paguen las dichas sus debdas, e que hera éste un caso fortytuyto, non prebisto nin pensado, y también el derecho 
quiere que en algunos casos se puedan demandar las debdas antes del tienpo en que se avían de pagar, por çiertas causas e razones que concurren en los dichos casos, las quales e mucho mayores estavan en éste para que las dichas debdas les fuesen pagadas, asy aquellas de las quales aún non es llegado el término de la paga dellas. E que en tal caso commo éste, según derecho, non se avían de guardar las reglas generales del derecho, más antes es liçito e permiso que se quiebren e traspasen la su preminençia e caso contengente de la salida suya e de los otros judíos destos nuestros reygnos. Por ende, que nos suplicavan e pedían por merçed, en aquella manera que mejor podían e devían, les mandásemos dar una buena persona syn sospecha por executor, para que brevemente les fiziese conplimiento de justiçia de los dichos sus debdores, que les pagasen asy las debdas que les son devidas commo de las otras, aunque el plazo sea llegado, según que la calidad del caso e brevedad del dicho tienpo lo requiere. $E$ mandásemos asymismo a los dichos sus crehedores que ayan de resçibir e resçiban en pago de sus debdas otras obligaçiones que ellos tenían sobre sus debdores. E asymismo mandásemos que ellos non fuesen obligados a pagar debdas algunas, a lo menos de aquellas que non hera llegado el plazo, fasta en tanto quellos fuesen contentos e satisfechos de las dichas debdas que les heran devidas, porque de otra manera ellos non ternían dineros para pagar lo que devían, o sobrello le proveyésemos lo que la nuestra miarçed fuese. Lo qual visto en el nuestro Consejo, fue acordado que porque lo suso dicho más brevemente fuese visto e determinado sobre ello lo que fuere justiçia, que devíamos mandar cometer lo suso dicho a una buena persona desa tierra e comarca para que brevemente, oydas las partes, determinase lo que fallase por justiçia. E nos tovímoslo por bien. E confiando de vos que soys tal persona que guardareys nuestro serviçio e el derecho a las partes, e bien e deligentemente fareys lo que por nos vos fuere mandado y encomendado, es nuestra merçed de vos encomendar e cometer lo suso dicho, e por la presente vos lo encomendamos e cometemos. Por que vos mandamos que veades lo suso dicho que de suso se faze mençión, e llamadas e oydas las partes a quien atañe, aunque sean los debdores que devan las tales debdas a ios dichos don Symuel de Soto e sus fijos de fuera de la dicha villa de Aranda, con çinco leguas alderedor, en qualquier juresdiçión que sea, synplemente e de plano, syn estrépitu e figura de juizio, non dando logar a dilaçiones de maliçia, salvo sólamente la verdad sabida, determinedes en ello lo que falláredes por justiçia por vuestra sentençia o sentençias, asy ynterlocutorias commo dyfinitivas. Las quales e el mandamiento o mandamientos que en la dicha razón diéredes e pronunçiáredes, podades llegar e lleguedes a pura e devida execuçión, con hefeto quanto e commo con derecho devades. E mandamos a las dichas partes e a otras 
qualesquier personas que para ello devan ser llamadas, que vengan e parezcan ante vos a vuestros llamamientos e enplazamientos, al plazo e so las penas que les vos posiéredes o mandáredes poner de nuestra parte. Las quales nos, por la presente, les ponemos e avemos por puestas. E por quanto por parte del dicho don Symuel de Soto e sus fijos nos fue dicho que por la nesçesidad e brevedad de la dicha su partida ellos non podrían cobrar las debdas que les son devidas, nin tenían dineros con qué pagar lo que devían a otras personas, e que sy se oviese de fazer execuçión en sus personas e bienes por las dichas debdas que ellos deven, resçiberan muy grande agravio e dapno, e sus bienes se venderían a malbarato, por saber commo saben todos la partida de los dichos judíos. Por ende, que nos suplicavan e pedían por merçed sobrello les mandásemos probeher de remedio con justiçia. E queriendo proveher sobre lo suso dicho, por la presente vos mandamos que, dando e nonbrando los dichos don Symuel de Soto e sus fijos bienes muebles e rayzes desenbargados que valgan la dicha quantya, los fagades tasar e moderar por dos buenas personas, una tomada por parte del dicho don Symuel de Soto e sus fijos, e la otra por parte de sus crehedores a quien esto tocare, sobre juramento, que primero fagan de lo tasar e moderar fielmente. E aquesto asy fecho, conpeled e apremiad al tal crehedor e crehedores de los dichos don Symuel de Soto e sus fijos que tomen e resçiban los dichos bienes asy tasados en la quantya que por los suso dichos fueren apresçiados para en pago de las dichas sus debdas. $E$ sy las dichas dos buenas personas non se conçertaren, les dedes e nonbredes un terçero. $E$ mandamos que valga lo quel dicho terçero, con los dichos dos buenos onbres fizieren, o con el uno dellos. E sy los dichos bienes asy apresçiados valieren algo más que la debda que fuere devida, que en tal caso el crehedor torne a los dichos don Symuel de Soto e sus fijos, sus debdores, la tal demasya e queden todos los dichos bienes para sy. E sy menos valieren que la dicha debda, quel dicho don Symuel e sus fijos, debdores, sehan obligados de pagar e suplir en dineros lo que asy faltare sobre los dichos bienes que asy fueren tasados e apresçiados. E faziéndolo e cunpliéndolo asy el dicho don Symuel e sus fijos, mandamos que non se faga nin sea fecha execuçión en sus personas, nin venta, nin remate de los dichos sus bienes. Para lo qual todo que dicho es, vos damos poder conplido por esta carta. Otrosy, por la presente tomamos e resçibimos al dicho don Symuel de Soto e sus fijos e a sus bienes durante el dicho tienpo de los dichos tres meses so nuestro seguro e anparo e defendimiento real. $E$ defendemos a todas e qualesquier personas e cavalleros que non sean osados de los ferir, nin matar, nin lisiar, nin prender, nin tomar nin enbargar sus personas e bienes, nin de les fazer nin mandar fazer otros algunos males e dapnos e desaguisados algunos contra razón e derecho commo non devan. 
E mandamos a vos, el dicho bachiller, e a todas e otras qualesquier nuestras justiçias, que lo fagan asy apregonar primeramente, porque venga a notyçia de todos, e dello non puedan pretender ynorançia. $E$ fecho el dicho pregón, sy alguna o algunas personas quebrantaren este nuestro seguro, pasedes e proçedades contra ellos e contra sus bienes a las penas que falláredes por fuero e por derecho. E non fagades ende al por alguna manera. Dada en la muy noble villa de Valladolid, a ocho días de! mes de mayo, año del nasçimiento de nuestro Señor Ihesu Christo de mill e quatroçientos e noventa e dos años. $E$ entiéndase todo lo suso dicho quanto a las debdas que son o fueren devidas a los dichos don Symuel de Soto e sus fijos, justa e líçitamente, e por contratos e otras escripturas permisas de derecho. Pero en quanto a las debdas que fueren de logro y usura, mandamos que se guarde e cunpla lo contenido en las leyes de nuestros reygnos. Alonso de Quintanilla. Gundisalvus, liçençiatus. Yo, Iohan Sánchez de Çehinos, la fiz escrivir por mandado del rey e de la reyna, nuestros señores, con acuerdo de los del su Consejo.

1492, mayo 17

Carta de comisión a los alcaldes de Aranda de Duero para que vean la queja de Garci Sánchez de Calahorra sobre unas deudas que con él tenía don Yuça de Soto, judío vecino de Aranda.- Consejo Real.

A.G.S., R.G.S., fol. 657, V-1492.

Don Fernando e doña Ysabel, e çetera. A los alcaldes de la villa de Aranda de Duero e a cada uno o qualquier de vos a quien esta nuestra carta fuere mostrada, o su traslado synado de escrivano público, salud e graçia. Sepades que Garçi Sánchez de Calahorra, vezyno de la dicha villa de Aranda, nos fizo relaçión por su petiçión, dezyendo que don Yuça de Soto, judío vezino de la dicha villa, le deve e está obligado a le dar e pagar, e a çiertos menores sus hermanos, fasta en quantía de veynte mill maravedíes, poco más o menos, e más una taça de plata, de marco e medio e dos onças. E allende desto, diz que deve al dicho Garçi Sánchez otros dos mill e quinientos maravedíes, de los quales diz que tiene su conosçimiento. Al qual dicho judío diz que ha pedido e demandado que le dé e pague los dichos maravedíes e taça ante vos, los dichos alcaldes. El qual diz que se opone, dezyendo que non tiene ninguna fazyenda de que pueda pagar, e que lo que tiene es de sus fijos, del casamiento de su madre, e poniendo e alegando otras muchas razones maliçiosas por se escusar de non pagar lo que asy 
deve, lo qual diz que faze porque se ha de yr muy prestamente fuera destos nuestros reynos syn le pagar cosa alguna. En lo qual sy asy oviese de pasar, diz quél e los dichos sus hermanos menores reçibyrían muy grande agravio e daño. Por ende, que nos suplicava e pedía por merçed çerca dello con remedio de justiçia le mandásemos proveer, mandándole dar nuestra carta para vos, los dichos alcaldes, para que brevemente le fezyésedes conplimiento de justiçia, conpeliendo e apremiando al dicho judío a que luego le diese e pagase lo que asy le deve a él e a los dichos sus hermanos, o le prendyésedes e arraygásedes fasta tanto que les pagase lo que asy les deve, o çerca de todo ello mandásemos proveer lo que la nuestra merçed fuese. E nos tovímoslo por bien, por que vos mandamos a vos, los dichos alcaldes, o a qualquier de vos, que veades lo suso dicho. E llamadas e oydas las partes a quien toca $e$ atañe, brevemente, syn dar logar a luengas ni dilaçiones de maliçia, salvo sólamente sabyda la verdad çerca dello, fagades e administredes todo conplimiento de justiçia al dicho Garçi Sánchez de Calahorra e a los dichos sus hermanos, por manera que la ellos ayan e alcançen, e por defecto della non ayan cabsa nin razón de se venir nin envyar más a quexar sobre ello ante nos. E non fagades ende al por alguna mane$\mathrm{ra}$, so pena de la nuestra merçed e de diez mill maravedíes para la nuestra Cámara a cada uno que lo contrario fezyere. E de más, mandamos al ome que vos esta nuestra carta mostrare, que vos enplaze que parescades ante nos en la nuestra corte, do quier que nos seamos, del día que vos enplazare fasta quinze días primeros seguientes, so la dicha pena. So la qual, mandamos a qualquier escrivano público que para esto fuere llamado, que dé ende al que vos esta nuestra carta mostrare testimonio synado con su sygno, por que nos sepamos en cómmo conplides nuestro mandado. Dada en la muy noble villa de Valladolid, a diez e syete días del mes de mayo, año del nasçimiento de nuestro Señor Ihesu Christo de mill e quatroçientos e noventa e dos años. Gundisalvus, liçençiatus. Françiscus, dottor e abbas. Yo, Sancho Ruyz de Cuero, secretario del rey a de la reyna, nuestros señores, la fize escrivir por su mandado, con acuerdo de los del su Consejo.

\section{8}

1492, mayo 22

Carta de comisión al bachiller Alfonso de Torres para que vea la demanda de García de Quemada sobre unas deudas que con él tenía don Yuça de Soto, judío vecino de Aranda de Duero.-

A.G.S., R.G.S., fol. 510, V-1492. 
Don Fernando e doña Ysabel, e çetera. A vos el bachiller Alfonso de Torres, nuestro vasallo, vezino de la villa de Aranda, salud e graçia. Sepades que por parte de Garçía de Quemada, vezino desa dicha villa, nos fue fecha relaçión por su petiçión que en el nuestro Consejo fue presentada, deziendo que don Yuça de Soto, judío vezino de esa dicha villa, diz que le deve çierta quantía de maravedíes, por los quales diz que le obligó y epotecó unas casas que son al varrio de Cascajal, en esa dicha villa. E que después diz que le ha puesto e pone dilaçiones por non le pagar los dichos maravedíes, deziendo que las dichas casas están obligadas al docte de su muger, e que las quiere vender para pagar el dicho docte a la dicha su muger, syn pagar lo que sobrellas diz que le deve, e que sy asy pasase, que él resçebiría grant dapno e pérdida. E fuenos suplicado e pedido por merçed que çerca dello le mandásemos proveer de remedio con justiçia, mandando al dicho don Yuça de Soto, judío, que luego le diese e pagase treynta e seys mill maravedíes que diz que le deve, e por que le tenía ypotecadas las dichas casas, e que sobrello non le traxiese en pleitos nin en rebueltas, o lo mandásemos cometer a una buena persona, syn sospecha, para que brevemente lo viese e determinase entrellos, o le mandásemos proveer en otra manera commo nuestra merçed fuese. E nos tovímoslo por bien, e confiando de vos que soys tal persona que guardareys nuestro serviçio e la justiçia a las partes, fue acordado de vos encomendar e cometer lo suso dicho, e por la presente vos lo encomendamos e cometemos. E vos mandamos que llamadas e oydas las partes, brevemente, non dando lugar a luengas nin dilaçiones de maliçia, syno la verdad sabida, fagades e administredes en ello al dicho Garçía de Quemada conplimiento de justiçia, e lo veades e determinedes por vuestra sentençia o sentençias, asy interlocutorias commo definitivas. Las quales o el mandamiento o mandamientos que en la dicha cabsa diéredes e pronunçiáredes, lleguedes e fagades llegar a pura e devida esecuçión, con efebcto quanto e commo e con fuero e con derecho devades. $E$ mandamos a las partes a quien lo suso dicho toca e atañe, e a otras qualesquier personas que para ello devan ser llamadas, que vengan e parezcan ante vos a vuestros llamamientos e enplazamientos, a los plazos e so las penas que de nuestra parte les pusiéredes. Las quales nos, por la presente, les ponemos e avemos por puestas. Para lo qual todo que dicho es, e para cada cosa e parte dello, vos damos poder conplido, con todas sus inçidençias e dependençias, e mergençias, anexidades e conexidades, e con todo lo a ello anexo e conexo, e dependiente. Dada en la muy noble villa de Valladolid, a veynte días del mes de mayo, año del nasçimiento del nuestro Señor Ihesu Christo de mill e quatroçientos e noventa e doss años. Gundisalvus, liçençiatus. Françiscus, doctor e abas. 
1492, mayo 22

Carta de comisión al bachiller Alfonso de Torres para que vea la queja presentada por don Symuel de Soto y otros judíos vecinos de Aranda de Duero sobre los contratos de préstamo que tenían con cristianos.- Consejo Real.

A.G.S., R.G.S., fol. 524, V-1492.

Don Fernando e doña Ysabel, e çetera. A vos el bachiller Alfonso de Torres, nuestro vasallo, vezino de la villa de Aranda, salud e graçia. Sepades que por parte de don Symuel de Soto, e de rabí Ça e de rabí Mose, sus fijos, vezinos de la dicha villa, nos fue fecha relaçión por su petiçión que en el nuestro Consejo presentó, deziendo que nos a vos ovimos mandado por una nuestra carta que todas las debdas que se deviesen a los suso dichos, e asymismo las quellos deviesen a otras qualesquier personas, vos lo viésedes e juzgásedes e fiziésedes en ello cunplimiento de justiçia, segund que más largamente diz que se contiene en la dicha nuestra carta. E diz que vos aveys conosçido e conosçeys de algunas de las dichas cabsas por vía hordinaria, e diz que non avedes querydo nin queredes proçeder por vía de esecuçión, commo quiera que vos han mostrado e muestran obligaçiones e contrabtos garentiçios de que son pasados los plazos, e tales que diz que trahen consygo aparejada esecuçión, e que en alguna esecuçión que diz que aveys fecho days término de treynta días e otras luengas e dilaçiones, de manera que diz que aunque toman las tales debdas por sentençia, que dexan pasar los plazos que les days para pagar. E asy pasados, diz que ahusentan los bienes muebles, e dizen e fazen esecuçión en la rayz, porque al tienpo del remate se pueda oponer a ellos, de manera que diz que pasan los términos e tienpos en que les avemos mandado salir destos nuestros reygnos e señoríos, e quellos non pueden cobrar lo que asy les es devido. $E$ asymismo diz que algunas personas e cavalleros desa comarca, cuyos son los lugares donde diz que les son devidas las dichas debdas, dizen que non consentirán que se fagan las tales esecuçiones, en lo qual diz que asymismo resçyben grande agravio e dapno. E otrosy, diz quellos tienen muchas prendas que les fueron enpeñadas por algunas personas de la dicha comarca, e que han fecho pregonar muchas vezes que las vengan a quitar sus dueños por lo que están enpeñadas, diz que non lo han querido nin quieren hazer a fin de ge lo pedir por pleito al tienpo de la partida, e les fazer detener, en lo qual diz que resçeberían muy mayor dapno e agravio. E fuenos suplicado e pedido por merçed que çerca dello les mandásemos 
proveer de remedio con justiçia, mandándovos que sy las dichas obligaçiones por ellos presentadas ante vos fueren pasados los plazos dellas e traxieren consygo aparejada esecuçión, que las esecutásedes e feziésedes esecutar en los bienes de los dichos debdores, e que los bienes muebles vendiésedes e rematásedes a terçero día, e la rayz a nueve días, porque en ello non se les diese dilaçión, e por que ellos se pudiesen despachar por salir de nuestros reygnos en el término por nos mandado. $E$ asymismo que non fuesen fatigados nin puestas otras demandas ante otros juezes, synon que vos fuésedes juez de todas sus cabsas, e que vos mandásemos que vendiésedes las dichas prendas que asy diz que tenían enpeñadas, por manera que ellos non toviesen nin les pudiesen poner ningund enbaraço nin inpedimento al tienpo de su partida, o les mandásemos proveer en otra manera commo nuestra merçed fuese. $E$ nos tovísmoslo por bien, por que vos mandamos que veades lo suso dicho, e en las obligaçiones e contratos e otras escrituras que por los suso dichos judíos ante vos fueren presentadas e pedida esecuçión dellas, sy los plazos fueren pasados e traxieren aparejada esecuçión, las esecutedes e fagades esecutar en bienes de los debdores, tanto quanto e commo con fuero e con derecho devades, e fagades e administredes en ello conplimiento de justiçia. E los contratos e obligaçiones e otras escrituras que ante vos por su parte fueren presentadas que non traxieren aparejada esecuçión, los veades. E llamadas e oydas las partes a quien toca, brevemente, e non dando lugar a dilaçiones de maliçia, synon la verdad sabida, fagades e administredes en ello conplimiento de justiçia. E lo veades e determinedes por vuestra sentençia o sentençias, asy interlocutorias commo definitivas, las quales e el mandamiento o mandamientos que en las dichas cabsas diéredes e pronunçiáredes, lleguedes e fagades llegar a pura e devida esecuçión, con efecto quanto e commo con fuero e con derecho devades. $E$ mandamos a las partes a quien lo suso dicho toca $e$ atañe, e a otras qualesquier personas que para ello devan ser llamadas, que vengan e parezcan ante vos a vuestros llamamientos e enplazamientos, a los plazos e so las penas que de nuestra parte les pusiéredes, las quales nos, por la presente, les ponemos e avemos por puestas. E otrosy, en lo que toca a las dichas prendas que asy diz que tienen enpeñadas, lo veades e determinedes, llamadas e oydas las partes, e fagades en todo ello conplimiento de justiçia, segund suso se contiene. Para lo qual todo que dicho es, e para cada cosa e parte dello, vos damos poder conplido, con todas sus inçidençias, e dependençias, e mergençias, anexidades e conexidades, e con todo lo a ello anexo e conexo e dependiente. E non fagades ende al. Dada en la muy noble villa de Valladolid, a veynte e doss días del mes de mayo, año del nasçimiento del nuestro Señor lhesu 
Christo de mill e quatroçientos e noventa e doss años, guardando sobre todo las leys de Madrigal por nos fechas, que fablan çerca de los logros e usuras. Gundisalvus, liçençiatus. Françiscus, doctor e abbas. Yo, Fernando de Çisneros, escrivano de Cámara del rey e de la reyna, nuestros señores, la fize escrevir por su mandado, con acuerdo de los del su Consejo. Guardando sobre todo las leys de Madrigal por nos fechas que fablan çerca de los logros e usuras.

1492, mayo 24

Carta de comisión a Juan de Ribera y al bachiller Alfonso de Torres para que vean todos los contratos de deudas que tienen varios judíos vecinos de Gumiel de Mercado con diversos cristianos de esta villa y su tierra.- Consejo Real.

$$
\text { A.G.S., R.G.S., fol. } 531, \text { V-1492. }
$$

Don Fernando e doña Ysabel, e çetera. A vos Juan de Ribera, vezino de la villa de Valladolid, y el bachiller Alfonso de Torres, vezino de la villa de Aranda, e a cada uno e qualquier de vos a quien esta nuestra carta fuere mostrada o su treslado signado de escrivano público, salud e graçia. Sepades que rabí Yuda, vezino de la villa de Gumiel de Mercado, por sí y en nonbre de Yuçe de Soto, judío, su hermano, e de Simuel de Soto, e de Sycorro, e de Haze, e de Symuel Soer, judíos vezinos de la dicha villa de Gumiel de Mercado, nos fizo relaçión por su petiçión que en el nuestro Consejo presentó, diziendo que a ellos les son devidas muchas debdas en la dicha villa de Gomiel de Mercado et su tierra, y en el balle de Bal de Esgueba, y en Ventosylla, y en la Horra, y en Aguilera, y en otros lugares comarcanos desa villa de Aranda. Y que a cabsa que ellos se han de yr destos nuestros reynos, según que por nos les está mandado, e que por ser la partyda tan brebe, ellos non podieran recabdar las dichas debdas que así le son debidas, a cabsa que las justiçias de las dichas villas e lugares diz que non les querrán hazer cunplimiento de justiçia. $E$ fuenos suplicado e pedido por merçed que çerca dello les mandásemos prober como nuestra merçed fuese, mandando cometer la determinaçión y esecuçión de lo suso dicho a una buena persona, syn sospecha, a la qual mandásemos que las debdas que paresçiesen que les heran devidas las exsecutasen vrebemente en bienes de los acrehedores, por manera que ellos oviesen e alcançasen brebemente cunplimiento de justiçia, mandando declarar los términos en que fiziesen las dichas esecuçiones e en que oviesen de 
vender los vienes en que se fiziesen, asy muebles commo rayzes. E otrosy, que mandásemos que las debdas que ellos devían a algunas personas, que dándoles en pago obligaçiones líquidas sobre çiertas de la comarca, seyendo de los mismos plazos e cantydad quellos deviesen, que ge las mandásemos reçebir en pago de las dichas debdas que asy devieren. $E$ que las obligaçiones quellos tyenen dadas a esecutar ante otras justiçias, que mandásemos que todo fuese remetydo a la tal persona que así por nos fuese nonbrada, el qual lo tomase en el estado en questoviese, e les fiziese brebemente cunplimiento de justiçia. E nos tovímoslo por bien, e confiando de vos, los suso dichos, e de cada uno e qualquier de vos, fue acordado de vos encomendar y cometer, e por la presente vos 10 encomendamos e cometemos. $E$ vos mandamos que veades los contratos e obligaçiones e otras escrituras que ante vos serán presentadas por parte de los dichos judíos o de qualquier dellos. E sy fuesen tales que traxieren consigo aparejada esecuçión, e los plazos en ellas contenidos fuesen pasados, seyendo los demandados de los que sean a quatro leguas desa dicha villa de Aranda, los esecutedes e fagades esecutar en bienes e personas de los dichos debdores e de cada uno dellos, tanto quanto e commo con fuero e con derecho devades. $E$ en las otras debdas que les fueren devidas e por ellos ante vos fueren pedidas e demandadas, de que non ovieren contratos e escrituras que trayan aparejada esecuçión, llamadas e oydas las partes a quien toca, brevemente, e non dando lugar a luengas nin dilaçiones de maliçia, syno la verdad sabida, fagades e administredes en ello vos, o qualquier de vos, conplimiento de justiçia, e lo veades e determinedes por vuestra sentençia o sentençias, así ynterlocutorias commo definitivas. Las quales o el mandamiento o mandamientos que en las dichas cabsas, o en qualquier dellas, diéredes e pronunçiáredes, lleguedes e fagades llegar a pura e devida esecuçión, con efecto quanto e commo con fuero e con derecho devades. $E$ mandamos a las partes a quien lo suso dicho toca e atañe, e a otras qualesquier personas que para ello devan ser llamadas, que vengan e parezcan ante vos o qualquier de vos, a vuestros llamamientos e enplazamientos, a los plazos e so las penas que de nuestra parte les pusiéredes e mandáredes poner, las quales nos, por la presente, les ponemos e avemos por puestas. Para lo qual todo que dicho es, e para cada cosa e parte dello, vos damos poder conplido a vos e a cada uno de vos insolidum, con todas sus inçidençias, e dependençias, e mergençias, anexidades e conexidades, e con todo lo a ello anexo e conexo e dependiente. E non fagades ende al. Dada en la muy noble villa de Valladolid, a veynte e quatro días del mes de mayo, año del nasçimiento del nuestro Señor Ihesu Christo de mill e quatroçientos e noventa e doss años. E esto vos mandamos que asy fagades e cunplades syendo las dichas debdas de 
contratos e negoçiaçiones líçitas e premisas, guardando en todo las leyes por nos fechas en las cortes de Madrigal, e otras que fablan sobre los contratos fechos de christiano a judío. Gundisalvus, liçençiatus. Françiscus, doctor e abas. Yo, Fernando de Çisneros, escrivano de Cámara del rey e de la reyna, nuestros señores, la fize escrevir por su mandado, con acuerdo de los del su Consejo.

1495, febrero 16

Carta de comisión a Alonso del Castillo, juez de los bienes que dejaron los judíos del Obispado de Osma, para que vea la queja de Juan Núñez de Calahorra, vecino de Aranda de Duero, en relación con unos contratos de deudas que había recibido de don Simuel de Soto, vecino que fue de esta villa.- Consejo Real.

A.G.S., R.G.S., fol. 492, II-1495.

Don Fernando e doña Ysabel, e çetera. A vos Alonso del Castyllo, nuestro juez de los bienes de los judyos del Obispado de Osma, salud e graçia. Sepades que Juan Núñez de Calahorra, vezino de la villa de Aranda, nos hizo relaçión e çetera, deziendo que al tienpo que nos mandamos salir los judíos fuera destos nuestros reynos, él avía puesto una demanda de fasta veynte mill maravedíes a un don Symuel de Soto, vezino de la dicha villa de Aranda, los quales diz que le devía de unas casas e bodega de çiertas cubas que le llevó por una deuda de çierto logro. La qual dicha demanda diz que le puso por ante un juez que por nos le fue dado al dicho Symuel de Soto e por ante escrivano público. E quél e otros que le pedían antel dicho juez çiertas debdas hezieron un pedymiento a la justiçia para que le prendyesen. El qual dyz questubo preso por las dichas, e que desque se vydo preso asentó e contrató con él e con un Juan Prieto, vezino de la dicha villa, que amos a dos saliesen e se obligasen a pagar de su hazyenda las dichas debdas e demandas que le estavan puestas, e quel dicho Juan Núñez non le pediesen, e que les dava fasta çiento e sesenta mill maravedíes que le devyan en la dicha villa e su comarca, de que diz que non hyzo çesyón nin traspasaçión, antes diz quél traspasó a ellos las dichas deudas e les dió las escrituras que tenían dellas. E que agora vos le aveys tomado las dichas escrituras e cobrays por ellas las dichas deudas que al dicho judío se devyan, sin le dar e pagar los maravedíes quel dicho judío le hera encargo, e syn le pagar ninguna cosa de lo quél ha gastado en lo cobrar fasta que por nuestro mandado le fueron enbargadas, en lo 
qual diz que sy asy pasase él reçebería mucho agravio e daño. E nos suplicó e pedió por merçed sobre ello le proveyésemos de remedio con justiçia, o commo la nuestra merçed fuese. E nos tovímoslo por bien, por que vos mandamos que conforme a los poderes e provisiones que de nos llevastes sobre las dichas deudas de los dichos judíos, llamadas e oydas las partes a quien atañe, brebemente, e syn dilaçión que ser pueda, non dando lugar a luengas nin dilaçiones de maliçia, salvo sólamente la verdad sabida, fagays e administreys al dicho Juan Núñez de Calahorra entero e brebe conplimiento de justiçia, por manera que la él aya e alcançe, e por defecto della non tenga cabsa nin razón de se nos más quexar sobre ello. $E$ los unos e los otros, e çetera. Dada en la villa de Madrid, a XVI de hebrero de $\mathrm{XCV}$ años. Don Álvaro lohanes, doctor. Andrés, doctor. Gundisalvus, liçençiatus. Felipus, doctor. Yo, Christóval de Vitoria, e çetera. 